\title{
Salinity strongly drives the survival, growth, leaf demography, and nutrient partitioning in seedlings of Xylocarpus granatum J. König
}

\author{
Mohammad Raqibul Hasan \\ Siddique ${ }^{(1)}$, \\ Sanjoy Saha ${ }^{(2)}$, \\ Serajis Salekin ${ }^{(1)}$, \\ Hossain Mahmood ${ }^{(1)}$
}

\begin{abstract}
Salinity is increasing in the Sundarbans (Bangladesh) due to sea-level rise and the reduction of fresh water flow. Xylocarpus granatum is one of the most valuable mangrove tree species of the Sundarbans. We conducted a six-month long study to investigate the effect of salinity on the survival, growth, leaf demography, and nutrient partitioning in parts of $X$. granatum seedlings. Our results showed that most of the seedlings (90\%) survived at 0 to 5 PSU salinity, and this survival percentage was found to decrease at higher saline conditions. Salinity of more than 25 PSU was lethal to the plants as no seedlings survived under these conditions. In this salinity (25 PSU), accelerated leaf fall coupled with a reduction in the new leaves caused loss of leaves. The relative growth rate (RGR) was higher at 0 to 5 PSU salinity, and conversely, a lower growth rate was observed with increased salinity. Higher saline conditions created stress, which inhibited nutrient ( $N, P$ and $K$ ) accumulation in different parts (leaf, stem, bark and root) of the seedlings. We concluded that salinity is a critical factor for the growth and survival of $X$. granatum either by inhibiting plant nutrient uptake or due to salinity related toxicity.
\end{abstract}

Keywords: Mangroves, Climate Change, Leaf Demography, Salinity, Sundarbans, Xylocarpus Granatum

\begin{abstract}
Introduction
Mangroves are the dominant woody vegetation of intertidal coastlines in the tropical, sub-tropical and warm temperate zones of the world (Mahmood et al. 2008), and these plants are constantly subjected to salinity ranging from seasonally freshwater (with traces of salinity) to hypersaline conditions (Ye et al. 2005, Nguyen et al. 2015). Salinity is known to limit propagule germination, seedling growth, and survival of mangroves (Mahmood et al. 2014a).

Several researchers have studied the growth of mangrove species under different salinity levels. For example, HoppeSpeer et al. (2011), Mahmood et al. (2014a), and Chen \& Ye (2014) found maximum biomass in salinity ranging from 0 to 10 PSU (Rhizophora mucronata at salinity 8 PSU, Heritiera fomes and Excoecaria agallocha at salinity range 0 to 5 PSU). How ever, further increases in salinity can slow

the biomass growth (Chen \& Ye 2014, Mahmood et al. 2014b). Reduction of leaf production accompanied with higher leaf mortality often leads to the death of the plant (Ball \& Pidsley 1995, Suárez \& Medina 2005). Leaf production and senescence are of vital physiological significance for plants as they govern the total leaf surface area per plant and leaf turnover rate (Reich et al. 1991). Leaf demography patterns at different salinity stress conditions provide important indications of salt balance (Clough et al. 1982). Higher saline conditions reduce the nutrient uptake and accumulation and can also affect nutrient partitioning in plant parts (Grattan \& Grieve 1999, Fernández-García et al. 2004). Differences in ion partitioning and the maintenance of higher nutrients such as $\mathrm{K}^{+}$to $\mathrm{Na}^{+}$ratios, especially in young tissues, may be an important mechanism for improving salt tolerance (Wei et al. 2003). Moreover, Khan et al.
\end{abstract}

(1) Forestry and Wood Technology Discipline, Khulna University, Khulna 9208 (Bangladesh); (2) Centre for Integrated Studies on the Sundarbans, Khulna University, Khulna 9208 (Bangladesh)

@ Mahmood Hossain (mahmoodhossain@hotmail.com)

Received: Jan 31, 2017 - Accepted: Jul 17, 2017

Citation: Siddique MRH, Saha S, Salekin S, Mahmood H (2017). Salinity strongly drives the survival, growth, leaf demography, and nutrient partitioning in seedlings of Xylocarpus granatum J. König. iForest 10: 851-856. - doi: 10.3832/ifor2382-010 [online 2017-10-26]

Communicated by: Claudia Cocozza
(2000) and Patel et al. (2010) stated that ion toxicity was due to saline stress. Salinity tolerance ranges vary considerably by mangrove species, and the range of salinity tolerance is an important determinant for plant growth and survival in their habitats (Nandy et al. 2007, Mahmood et al. 2014b). Allen et al. (2003) reported that seedlings of Xylocarpus granatum can grow in 23 PSU salinity without any visible stress signs, but they add that growth is much better in non-saline conditions. However, in the Sundarbans, $X$. granatum commonly occurs in moderately (15 to $25 \mathrm{PSU}$ ) saline areas. Xylocarpus granatum is a medium sized, less branched, exclusive mangrove tree species that normally flowers either in premonsoon (March-May) or post-monsoon time (October-December). Fruits, consequently, may come either in May-July or in December-February, and each fruit contains approximately 4-6 semi-triangular seeds. Both fruits and seeds are buoyant and water dispersed, and seeds show epigeal germination (Mahmood 2015). Seed germination is greater in less saline conditions (approximately 60\%) than in high saline conditions (approximately $20 \%$ Mahmood et al. 2014a). Xylocarpus granatum is considered to be a salt accumulating species (Paliyavuth et al. 2004) and occurs in association with $\mathrm{H}$. fomes, Avicennia officinalis or Brugeira gymnorrhiza. Xylocarpus granatum covers $3.09 \%$ of the total vegetated area of the Sundarbans, which declined at a rate of $0.10 \%$ year $^{-1}$ during the 1926-1997 period (Iftekhar \& Saenger 2008). Assuming increased salinities might 


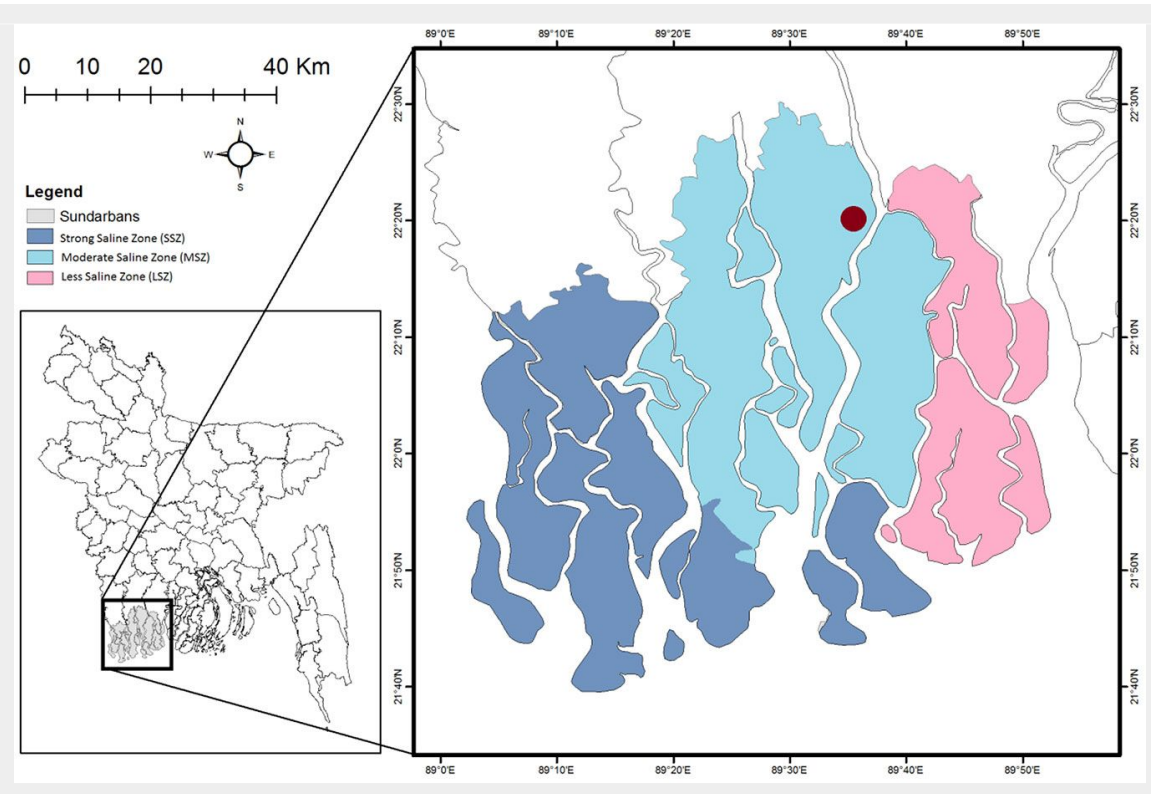

Fig. 1 - Salinity zones in the Sundarbans and the red circle is the sample collection site.

prevent the recovery and reduce the abundance of $X$. granatum as a consequence of seedling failure, we aimed to determine whether $X$. granatum can change its salinity tolerance over time. We wanted to investigate what its salinity tolerance over time would be at each developmental stage. We conducted our study with $X$. granatum seedlings, as the juvenile stage is more sensitive compared to adults, and $X$. granatum will increase its salinity tolerance with age.

Evidence suggests that salinity is increasing in the Sundarbans due to sea-level rise in association with reduced fresh water flow from upstream (Gopal \& Chauhan 2006). The present study examined the effect of salinity on seedling survival and growth, leaf demography, nutrient ( $N, P$ and $\mathrm{K}$ ) and sodium distribution in different parts of $X$. granatum seedlings. Investigating the relationship of these characteristics to salinity should facilitate a better understanding of the leaf and growth dynamics of this mangrove species. Furthermore, these adaptations may help to elucidate the future status of this species in relation to the consequences of climate change.

\section{Materials and methods}

Site description and seed collection and seedling raising

Mature fruits were plucked and collected from several healthy $X$. granatum trees from the Chandpai range of the Sundarbans, Bangladesh ( $89^{\circ} 36^{\prime} 31.068^{\prime \prime} \mathrm{E}, 22^{\circ} 20^{\prime}$ 11.832" N) during June and July (Fig. 1). The fruit collection site was in a 10-25 PSU saline zone with an average elevation of 0.9 to $2.1 \mathrm{~m}$ above mean sea level and can therefore be classified as mesohaline zone according to Siddiqi (2001). The site is nearly $200 \mathrm{~m}$ away from the Passur River. The land is low and flat and dominated by silty clay loam or alluvium (Islam 2003) with an alternate layer of clay and sand, which is mostly neutral to mildly alkaline in nature. The area becomes waterlogged during the full moon, though there are two high tides per day where it remains dry except during the rainy season when it becomes waterlogged twice a day by high tide. The salinity of the river decreases rapidly with the increase of freshwater flow after the dry season (minimum salinity in August-September) and increases steadily after the

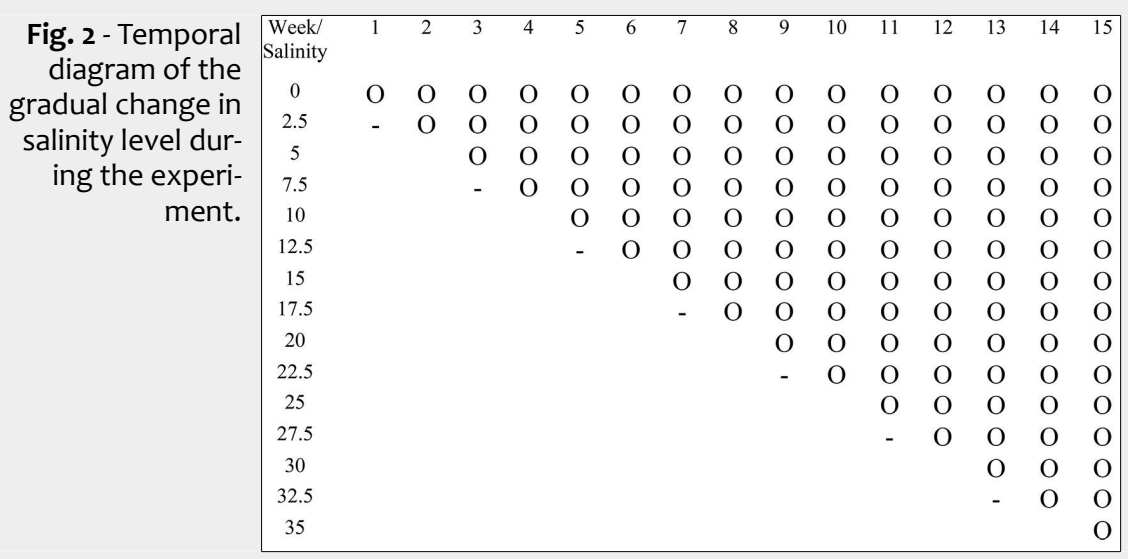

freshwater flow reduction in the post-monsoon period (April-May) as the area is situated in the eastern part (except at the river mouth) according to Siddiqi (2001). Due to the strong seasonal climate, $87 \%$ of the annual precipitation $(1500 \mathrm{~mm})$ occurs between May and October, and the other months are considered dry with little or no precipitation (Siddiqi 2001). Maximum and minimum temperatures range from 18 to $35^{\circ} \mathrm{C}$ in summer and 12 to $29^{\circ} \mathrm{C}$ during winter. The site is dominated by $\mathrm{H}$. fomes with a scattered distribution of $X$. granatum.

Sampled fruits are globose up to $18-24 \mathrm{~cm}$ in diameter, and each fruit contains an average of 4-6 seeds. Seeds with visible defects were discarded from the study. Germination was initiated by placing the seeds on the surface of coarse sand ( 0.5 $\mathrm{mm}$ to $1 \mathrm{~mm}$ ) in a $15-\mathrm{cm}$ thick germination bed. Daily water was provided early in the morning and late in the afternoon to maintain a high level of moisture, compensating for evaporative loss.

\section{Seedling survival, growth and leaf demography}

Each six-month-old individual seedling was placed in a coarse sand-filled PET bottle ( $9 \mathrm{~cm}$ in diameter and $20 \mathrm{~cm}$ in height), and a total of 156 seedlings were prepared. For each seedling, fresh weight of the whole plant including the stem, roots and leaves was measured and recorded. The number of leaves per seedling was counted and recorded at the beginning of the experiment, and the number of newly grown leaves and leaves shed (by counting the leaf marks left by the fallen leaves on the stem) per seedling was counted and recorded throughout the experiment. The fresh to oven-dried weight conversion ratio was calculated from 12 seedlings after drying them at $80{ }^{\circ} \mathrm{C}$ for 4 days. A total of 6 bottles with seedlings were placed in a plastic box $(20 \times 15 \times 12 \mathrm{~cm})$, and thus, 24 boxes were prepared, which were exposed to different salinity treatments (0-35 PSU, at 5 PSU intervals) with 3 replicates for each treatment. Each of the boxes was irrigated with 5 liters of modified full strength Hogland nutrient solution. Different salinity levels of this nutrient solution were maintained by preparing the $1000 \mathrm{ppm}$ stock solution of commercially available $\mathrm{NaCl}$. Hogland solution was modified to avoid further contamination of $\mathrm{Na}^{+}$and $\mathrm{Cl}^{-}$ from the nutrient composition of this solution (Mahmood et al. 2014a). The depth of the nutrient solution was maintained up to the collar height of seedlings, and the salinity levels were checked daily by using a portable hand salinity refractometer (RHS4/ATC). The water level was marked in each of the boxes and checked daily; if necessary, distilled water was added up to the mark to compensate for evaporative loss.

The initial salinity of the nutrient solution was o (zero) PSU. At the second week, the salinity of the first treatment was kept at 0 PSU, and all other treatments were 
Fig. 3 - Effects of salinity on seedlings of Xylocarpus granatum: (a) survival; (b) leaf demography; (c) specific leaf area; and (d) growth. Values are means of three replicates with six seedlings per replicate.

Means at the same salinity with different letters are significantly different

$(p<0.05)$ according to oneway ANOVA test.
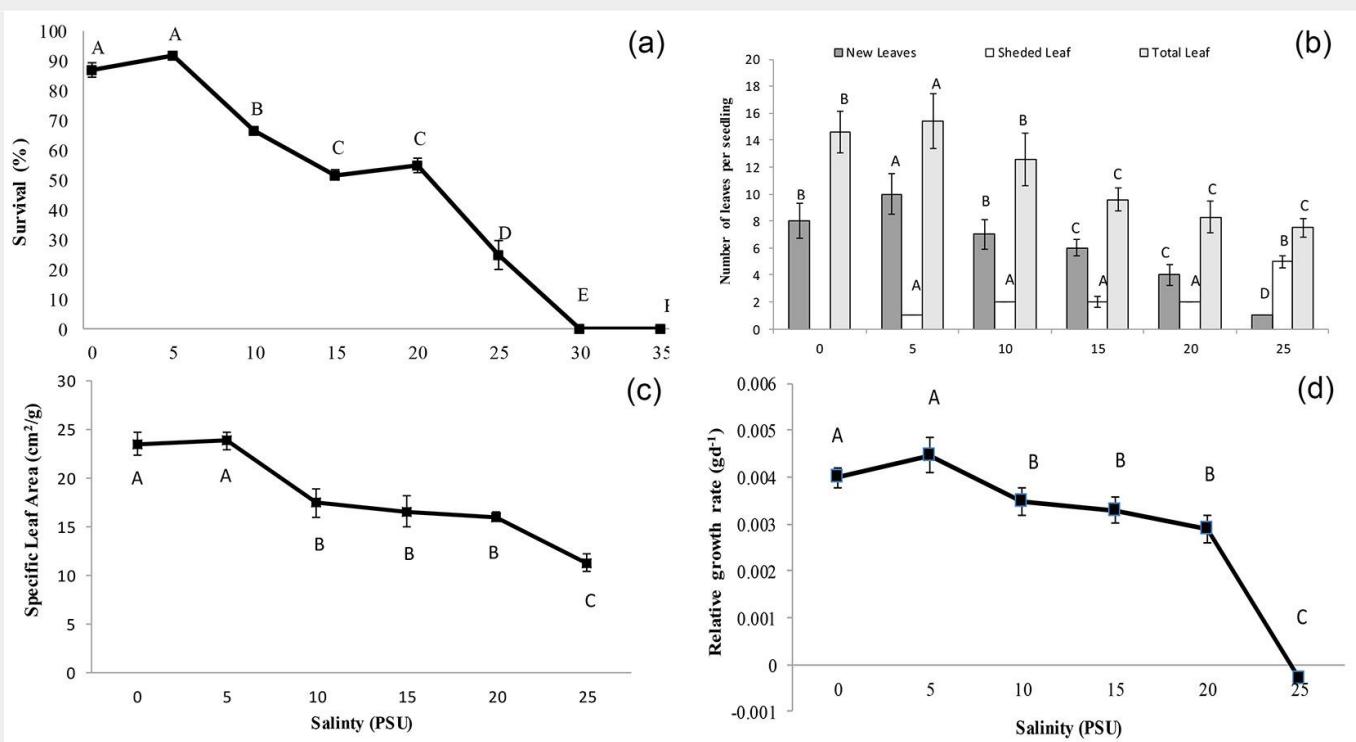

(c)

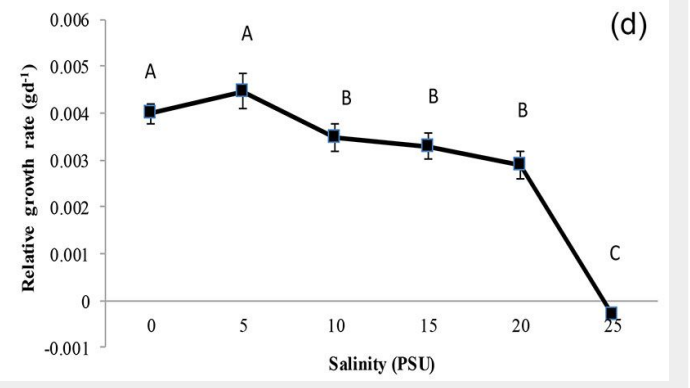

increased to 2.5 PSU. At the $3^{\text {rd }}$ week, the salinity of the first treatment was kept at 0 PSU, but the other treatments were increased by another 2.5 PSU. At the $4^{\text {th }}$ week, the salinity of the first treatment was kept at O PSU, and the second treatment was kept at 5 PSU, while all other treatments were increased by 2.5 PSU. Thus, the salinity of the solution was gradually increased from 0 to 35 PSU in the respective treatments following the above method (Fig. 2). Salinity was increased gradually as it helps the seedlings to cope with the sudden shock of salt stress. The solution was replaced weekly, and salinity levels were checked regularly. The $\mathrm{pH}$ in the nutrient medium was maintained at 7.5-8 for all the treatments. After reaching their final salinity level, every seedling was kept for 25 weeks in an uncontrolled glasshouse under natural temperature and light and then harvested. At the end of the experiment, the number of surviving seedlings was counted before they were harvested, and the green final biomass of each seedling including stem, roots and leaves was taken. The leaf area was measured by using Fiji ImageJ software (Schindelin et al. 2012), and the relative growth rate (RGR, mg $\mathrm{g}^{-1} \mathrm{~d}^{-1}$ ) was calculated according to Kriedemann et al. (2014 - eqn. 1):

$$
R G R=\frac{\ln B_{t}-\ln B_{0}}{t_{t}-t_{0}}
$$

where $B_{\mathrm{t}}$ is the final biomass of the seedlings measured at the time of harvest, and $B_{0}$ is the initial dry biomass of the seedling estimated from the fresh to oven dry weight conversion ratio. Specific leaf area (SLA, $\mathrm{cm}^{2} \mathrm{~g}^{-1}$ ) was obtained by dividing the leaf area by leaf biomass.

Measurements of nutrients (N, P and $K)$, and sodium in seedling parts

Tree seedling parts (leaves, bark, stems and roots) were collected from the harvested seedlings of each treatment and crushed to $1.0 \mathrm{~mm}$ particle size by sieving to ensure homogeneity. After thorough mixing of the sieved samples, approximately $100 \mathrm{~g}$ of subsamples were taken for oven-drying at $60^{\circ} \mathrm{C}$ for 4 days. The ovendried samples were processed and acid digested according to Allen (1989). Nitrogen and $\mathrm{P}$ in the sample extract were measured according to Baethgen \& Alley (1989) and Olsen \& Sommers (1982), respectively. Potassium (K) and sodium ( $\mathrm{Na}$ ) in the sample extract were measured by a Flame photometer (PFP7, Jenway LTD, England).

\section{Statistical analysis}

The survival percentages were arcsine transformed and then compared among the treatments by one-way Analysis of Variance (ANOVA) followed by Least Significant Difference (LSD) tests. Additionally, correlation among the survival and growth parameters of seedlings and salinity treatments was conducted using SAS v. 6.12 statistical software. Relative Growth Rate (RGR), Specific Leaf Area (SLA) and Leaf Area Ratio (LAR) in different salinity treatments were also compared by one-way ANOVA followed by LSD tests. Nitrogen $(\mathrm{N})$, Phosphorus (P), Potassium (K) and Sodium $(\mathrm{Na})$ concentrations in different parts of seedlings in different salinity treatments were compared by two-way ANOVA followed by LSD tests. N, P, K and Na relationships with salinity were evaluated through Pearson's correlation analysis using SAS v. 6.12 statistical software.

Tab. 1 - ANOVA table for the effects of salinity on the survival, leaf demography and growth of Xylocarpus granatum seedlings.

\begin{tabular}{lcrrc}
\hline Sources of Variation & df & Mean Square & F Value & P \\
\hline Survival & 7 & 11008.84 & 370.02 & 0.0001 \\
Total Leaf & 5 & 252.86 & 5.91 & 0.0001 \\
New Leaf & 5 & 115.81 & 6.88 & 0.0001 \\
Shaded Leaf & 5 & 8.59 & 6.72 & 0.0033 \\
Specific Leaf Area & 5 & 595.10 & 8.42 & 0.0001 \\
Relative Growth Rate & 5 & 0.00002557 & 9.92 & 0.0001 \\
\hline
\end{tabular}

\section{Results}

The highest survival (87\% to $92 \%$ ) of seedlings was observed at o to 5 PSU saline conditions, and the rate of survival started to decrease significantly $(\mathrm{p}<0.05)$ with increasing salinity. The lowest survival (25\%) was observed at 25 PSU salinity (Fig. 3a, Tab. 1). The survival of seedlings showed a significant $(p<0.05)$ strong negative correlation $(r=-0.94)$ with salinity. Hence, the effect of salinity on seedling growth was only considered up to a salinity level of 25 PSU.

The highest number of new leaves (10) and consequently the highest number of total leaves (15) per seedling was observed at 5 PSU salinity, and the number of new leaves as well as total leaves decreased significantly $(p<0.05)$ with increasing salinity. Conversely, the highest number of leaves shed per seedling (5) was observed at 25 PSU and decreased significantly $(p<0.05)$ with decreasing salinity (Fig. 3b, Tab. 1). Accelerated senescence of leaves coupled with reduced numbers of newly initiated leaves at salinities of 20 and 25 PSU resulted in loss of leaf over time. The number of newly grown leaves showed a significant negative correlation $(r=-0.85)$ with salinity, whereas the number of shed leaves was positively correlated $(r=0.93)$ with salinity. The highest specific leaf area $\left(24 \mathrm{~cm}^{2} \mathrm{~g}^{-1}\right)$ was observed at 0 to 5 PSU salinity conditions, and the leaf area significantly $(p<0.05)$ declined with increasing 

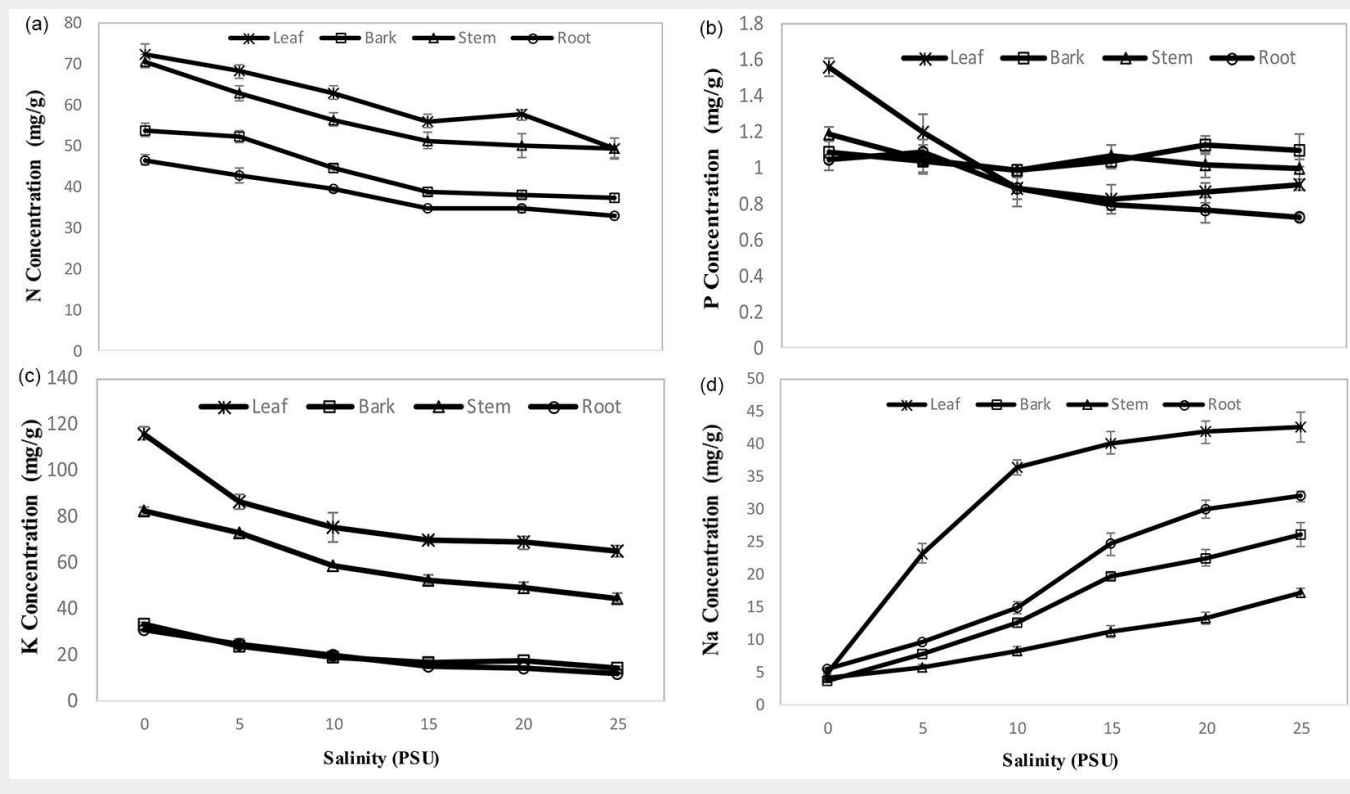

Fig. 4 - Effects of salinity on nutrients concentration in seedlings of Xylocarpus granatum. (a) Nitrogen; (b) Phosphorus; (c) Potassium and (d) Sodium. Values are means of three replicates with six seedlings per replicate. salinity $\left(11 \mathrm{~cm}^{2} \mathrm{~g}^{-1}\right.$ in 25 PSU salinity) conditions (Fig. 3c, Tab. 1). The specific leaf area showed a significant $(\mathrm{p}<0.05)$ negative correlation $(r=0.95)$ with salinity.

Seedlings of $X$. granatum grew best at 0 PSU (0.004 $\left.\mathrm{g} \mathrm{d}^{-1}\right)$ to 5 PSU (0.0045 $\left.\mathrm{g} \mathrm{d}^{-1}\right)$, but the growth of seedlings was significantly $(p<0.05)$ compromised at elevated saline conditions (Fig. 3d, Tab. 1), and at a salinity of 25 PSU, the relative growth rate was negative. Relative growth rate showed

a significant negative correlation $(r=-0.83)$ with salinity.

Significant differences in nitrogen $(F=$ 121.72, $p<0.0001)$, phosphorus $(F=5.71, p$ $<0.0001)$, potassium $(F=148.07, p<0.0001)$ and sodium $(F=59.36, p<0.0001)$ concentrations were observed for different parts of $X$. granatum seedlings at different salinity levels. Comparatively, the highest $(\mathrm{p}<0.05)$ concentration of $\mathrm{N}\left(72 \mathrm{mg} \mathrm{g}^{-1}\right)$ was observed in leaves, followed by stems, bark

Tab. 2 - ANOVA table for the effects of salinity on nutrient partitioning of Xylocarpus granatum seedlings.

\begin{tabular}{llcccc}
\hline \multicolumn{2}{c}{ Sources of Variation } & df & Mean Square & F Value & Prob. \\
\hline $\mathrm{N}$ & Leaf & 5 & 203.443 & 26.03 & $<0.0001$ \\
& Bark & 5 & 163.154 & 39.68 & $<0.0001$ \\
& Stem & 5 & 306.198 & 22.85 & $<0.0001$ \\
& Root & 5 & 86.6544 & 30 & $<0.0001$ \\
\hline $\mathrm{P}$ & Leaf & 5 & 0.07528 & 3.34 & 0.0404 \\
& Bark & 5 & 0.0078 & 0.8 & 0.5716 \\
& Stem & 5 & 0.01728 & 1.1 & 0.4083 \\
& Root & 5 & 0.27461 & 7.59 & 0.002 \\
$\mathrm{~K}$ & Leaf & 5 & 165.439 & 38.3 & $<0.0001$ \\
& Bark & 5 & 141.106 & 44.93 & $<0.0001$ \\
& Stem & 5 & 716.098 & 211.12 & $<0.0001$ \\
& Root & 5 & 1093.99 & 14 & $<0.0001$ \\
$\mathrm{Na}$ & Leaf & 5 & 670.825 & 92.17 & $<0.0001$ \\
& Bark & 5 & 222.447 & 68 & $<0.0001$ \\
& Stem & 5 & 72.2391 & 55.03 & $<0.0001$ \\
& Root & 5 & 364.349 & 115.12 & $<0.0001$ \\
\hline
\end{tabular}

Tab. 3 - Correlation (Pearson) among salinity level and nitrogen, phosphorus, potassium and sodium in different parts of Xylocarpus granatum seedlings (Values are means of three replicates with six seedlings per replicate and $p<0.05$ ).

\begin{tabular}{ccccc}
\hline \multirow{2}{*}{ Elements } & \multicolumn{2}{c}{ Plant Parts } & & \\
\cline { 2 - 5 } & Leaf & Bark & Stem & Root \\
\hline $\mathrm{N}$ & -0.97 & -0.95 & -0.93 & -0.97 \\
$\mathrm{P}$ & -0.82 & 0.38 & -0.71 & -0.95 \\
$\mathrm{~K}$ & -0.97 & -0.91 & -0.95 & -0.86 \\
$\mathrm{Na}$ & 0.89 & 0.99 & 0.99 & 0.99 \\
\hline
\end{tabular}

and then roots (Fig. 4a, Tab. 2). The highest concentration of $\mathrm{P}\left(1.56 \mathrm{mg} \mathrm{g}^{-1}\right)$ was detected in leaves, but similar concentrations were observed for bark, roots and stems at different salinities (Fig. 4b, Tab. 2). In the case of $K$, comparatively, the highest ( $p$ $<0.05)$ concentration $\left(116.5 \mathrm{mg} \mathrm{g}^{-1}\right)$ was observed in leaves followed by stems, roots and bark. However, the concentration was very similar for bark and roots (Fig. 4c, Tab. 2). Comparatively, the highest $(\mathrm{p}<0.05) \mathrm{Na}$ concentration ( $42.57 \mathrm{mg} \mathrm{g}^{-1}$ ) was observed in leaves followed by roots, bark and stems (Fig. 4d, Tab. 2). The concentration of nutrients was comparatively higher $(p<0.05)$ at 0 to 5 PSU salinity conditions, and with the increase of salinity, the concentration of nutrients was compromised in all parts of seedlings except for $\mathrm{P}$ in bark and stems (Fig. 4). N, P and K concentrations in different parts of seedlings showed significant $(p<0.05)$ negative correlations with salinity, while $\mathrm{Na}$ concentration showed a significant positive $(p<0.05)$ correlation. The sodium concentrations in plant parts showed a significant $(p<0.05)$ inverse relationship with potassium in the respective plant parts (Tab. 3).

\section{Discussion}

Higher survival of seedlings was observed in non-saline to slightly saline conditions ( 0 to $5 \mathrm{PSU}$ ), and the survival percentage was reduced with increased salinity, similar to the findings of Ball et al. (1988), Houle et al. (2001), and Nandy et al. (2007). Higher survival in non-saline to slightly saline conditions suggests that salt is not a requirement for the growth of a mangrove species such as $X$. granatum (Krauss \& Ball 2013). Beyond the salinity 25 PSU, no seedlings survived, and as a result, salinity over 25 PSU was considered a threshold for the survival of $X$. granatum species (Fig. 2a). Similarly, Ye et al. (2005) found lower survival for Aegiceras corniculatum at 25 PSU, and Chen \& Ye (2014) found 25 PSU salinity 
to be lethal for Excoecaria agallocha.

Reduced leaf production, decreased specific leaf area and increased leaf senescence with increased salinity is in accordance with the findings of Ball \& Pidsley (1995) and Chen \& Ye (2014). Leaf area reduction is considered to be the immediate response to salt stress (Parida \& Das 2005, Reef \& Lovelock 2015). Increased salt concentration leads to an increase in leaf shedding, as it is one of the mechanisms used by halophytes in high salinity conditions (Krauss et al. 2008) to remove excess salt. The accelerated leaf senescence and mortality of $X$. granatum seedlings at 25 PSU was accompanied by little leaf production, resulting in negative foliage gain over time. This suggests that although they survived the duration of the experiment, older seedlings of $X$. granatum cannot survive at this salinity in the long term.

Differences in $\mathrm{N}, \mathrm{P}, \mathrm{K}$ and $\mathrm{Na}$ in various seedling parts in our study are similar to the findings of Mahmood et al. (2014a). Nitrogen, $\mathrm{P}$ and $\mathrm{K}$ are more abundant in leaves as they are physiologically active and help in photosynthesis (Mahmood et al. 2006, Taffouo et al. 2008). The higher amount of $K$ in leaves suggests that $K$ is a principal element responsible for osmotic adjustment, which contributes to the salt regulation mechanism (Wei et al. 2003). The higher concentration of $\mathrm{Na}$ in leaves of $X$. granatum contradicts the findings of Taffouo et al. (2008) for Citrullus lanatus and Cucurbita moschata in Cameroon. This variation may represent species-specific accumulation of salt in their leaves. Additionally, as a salt accumulator, $X$. granatum (Paliyavuth et al. 2004) may expel excess salt by dropping leaves (Munns 1992), which is also supported by the results from our leaf demography study.

Nutrient imbalance in plants due to salinity stress (Grattan \& Grieve 1999) may be attributed to reduced leaf numbers and leaf area (Ball \& Pidsley 1995, Suárez \& Medina 2005), which implies that the productivity of the plant is affected by salinity (Franco 1985). The reduction in nutrient concentrations ( $\mathrm{N}, \mathrm{P}$ and $\mathrm{K}$ ) corresponding with increasing salinity may indicate a barrier provided by salinity to the uptake and accumulation of nutrients, or affect nutrient partitioning within the plant (Fernández-García et al. 2004). However, the extent of this relationship varies with species and plant parts (Grattan \& Grieve 1999). Nonetheless, no variation in $\mathrm{P}$ of bark and stems with respect to salinity may be due to ontogeny, salinity level or species-specificity (Grattan \& Grieve 1999). The antagonistic relationship among sodium and potassium found in the present study suggests that sodium inhibited the uptake of potassium (Mahmood et al. 2014a).

Reduced growth associated with increasing salinity was also reported with Ceriops australis and C. decandra in Australia (Ball 2002), $\mathrm{H}$. fomes in Bangladesh (Mahmood et al. 2014a), and A. germinans in Venezuela
(Lopez-Hoffman et al. 2007). Further, Ye et al. (2005) found a significant increase of RGR from 0 to 5 PSU, with a significant decrease in RGR at salinities over 15 PSU; the highest value was at low (5 PSU) to moderate salinities (15 PSU) for three saltsecreting mangrove species (Acanthus ilicifolius, Aegiceras corniculatum and Avicennia marina). However, we found no significant difference from 0 to 5 PSU salinity both in survival percentage and RGR in our study, which may be attributed to the efficiency of salt regulation up to 5 PSU by the plants.

Nutrients are essential to perform different physiological functions (such as respiration, transpiration and photosynthesis) of plants (Marschner 1995). High salinity affects plant growth through sodium induced toxicity or by causing nutrient deficiency/disorder or a combination of those factors (Läuchli \& Grattan 2007). This could be the reason we observed higher RGR at 0 to 5 PSU salinity and vice versa. Ball \& Pidsley (1995) observed similar results while studying Sonneratia lanceolata. Thus, we can conclude that salinity is a critical factor for the development, survival and growth of mangrove seedlings and that the effect of salinity depends on the species-specific salt tolerance range (Houle et al. 2001, Nandy et al. 2007). In low salinity conditions, mangroves usually deploy most of their energy for growth and development. Conversely, most of the energy is utilized for survival at higher salinities (Suárez \& Medina 2005) to help develop salinityinduced physiological changes (Munns \& Tester 2008). These changes could be the reason we observed comparatively higher survival and growth of $X$. granatum seedlings at lower salinities.

\section{Conclusion}

Salinity is a driving factor for the survival, growth, development and nutrient partitioning in plant parts of mangrove species. The studied species is known as a moderated salt tolerant species in the Sundarbans. However, climate change consequences (sea level rise, change in rainfall amount and pattern, saline intrusion due to the withdraw of fresh water flow from the upstream of the Sundarbans) may lead to increase the salinity in the studied area. The increase in salinity up to more than 25 PSU in the Sundarbans may cause threat on the natural regeneration and recruitment of this species. Therefore, sustainable flow of fresh water in the Sundarbans may protect the extinction of this species from its habitat.

\section{Acknowledgements}

We are thankful to United States Department of Agriculture (USDA) for their financial support; Ministry of Education and University Grants Commission, Bangladesh for their monitoring and smoothing the project activities. We also acknowledge the Sundarbans East Forest Division, and
Forestry and Wood Technology Discipline, Khulna University for the logistic support.

\section{References}

Allen JA, Krauss KW, Hauff RD (2003). Factors limiting the intertidal distribution of the mangrove species Xylocarpus granatum. Oecologia 135 (1): 110-121. - doi: 10.1007/s00442-002-1167-2 Allen S (1989). Chemical analysis of ecological materials ( $2^{\text {nd }}$ edn). Blackwell, Oxford, UK, pp. 368.

Baethgen WE, Alley MM (1989). A manual colorimetric procedure for measuring ammonium nitrogen in soil and plant Kjeldahl digests. Communication in Soil Science and Plant Analysis 20 (9-10): 961-969. - doi: 10.1080/0010362890936 8129

Ball M, Cowan IR, Farquhar GD (1988). Maintenance of leaf temperature and the optimization of carbon gain in relation to water loss in a tropical mangrove forest. Functional Plant Biology 15 (2): 263-276. [online] URL: http://www. publish.csiro.au/fp/PP9880263

Ball MC (2002). Interactive effects of salinity and irradiance on growth: implications for mangrove forest structure along salinity gradients. Trees 16 (2-3): 126-139. - doi: 10.1007/s00468002-0169-3

Ball MC, Pidsley SM (1995). Growth responses to salinity in relation to distribution of two mangrove species, Sonneratia alba and S. lanceolata, in northern Australia. Functional Ecology 9: 77-85. - doi: 10.2307/2390093

Chen Y, Ye Y (2014). Effects of salinity and nutrient addition on mangrove Excoecaria agallocha. PLoS ONE 9 (4): e93337. - doi: 10.1371/journal. pone.0093337

Clough BF, Andrews TJ, Cowan IR (1982). Physiological processes in mangroves. In: “Mangrove ecosystems in Australia: Structure, function, and management" (Clough BF ed). Australian National Press, Canberra, Australia, pp. 193-210. Fernández-García N, Martínez V, Carvajal M (2004). Effect of salinity on growth, mineral composition, and water relations of grafted tomato plants. Journal of Plant Nutrition and Soil Science 167 (5): 616-622. - doi: 10.1002/jp In.200420416

Franco M (1985). A modular approach to tree production. In: "Studies on Plant Demography" (White J ed). Academic Press, London, UK, pp. 257-272.

Gopal B, Chauhan M (2006). Biodiversity and its conservation in the Sundarbans mangrove ecosystem. Aquatic Science 68 (3): 338-354. - doi: 10.1007/s00027-006-0868-8

Grattan SR, Grieve CM (1999). Mineral nutrient acquisition and response by plants grown in saline environments. In: "Handbook of Plant and Crop Stress ( $2^{\text {nd }}$ edn)" (Pessarakli $M$ ed). CRC Press, New York, USA, pp. 203-229. [online] URL: http://books.google.com/books? id=xsobnIXZBwQC

Hoppe-Speer SC, Adams JB, Rajkaran A, Bailey D (2011). The response of the red mangrove Rhizophora mucronata Lam. to salinity and inundation in South Africa. Aquatic Botany 95 (2): 7176. - doi: 10.1016/j.aquabot.2011.03.006 Houle G, Morel L, Reynolds CE, Siégel J (2001). The effect of salinity on different developmental stages of an endemic annual plant, Aster 
laurentianus (Asteraceae). American Journal of Botany 88 (1): 62-67. - doi: 10.2307/2657127

Iftekhar MS, Saenger P (2008). Vegetation dynamics in the Bangladesh Sundarbans mangroves: a review of forest inventories. Wetland Ecology and Management 16 (4): 291-312. - doi: 10.1007/s11273-007-9063-5

Islam MS (2003). Perspectives of the coastal and marine fisheries of the Bay of Bengal, Bangladesh. Ocean and Coastal Management 46: 763-796. - doi: 10.1016/S0964-5691(03)00064-4 Khan MA, Ungar IA, Showalter AM (2000). Effects of salinity on growth, water relations and ion accumulation of the subtropical perennial halophyte, Atriplex griffithii var. stocksii. Annals of Botany 85 (2): 225-232. - doi: 10.1006/ anbo.1999.1022

Krauss KW, Ball MC (2013). On the halophytic nature of mangroves. Trees 27 (1): 7-11. - doi: 10.1007/s00468-012-0767-7

Krauss KW, Lovelock CE, McKee KL, López-Hoffman L, Ewe SM, Sousa WP (2008). Environmental drivers in mangrove establishment and early development: a review. Aquatic Botany 89 (2): 105-127. - doi: 10.1016/j.aquabot.2007.12.014

Kriedemann P, Virgona J, Atkin O (2014). Growth analysis: a quantitative approach. In: "Plants in Action, Adaptation in Nature, Performance in Cultivation ( $2^{\text {nd }}$ edn)" (Price C, Munns R eds). Australian and New Zealand Societies of Plant Sciences, web site. [online] URL: http:// plantsinaction.science.uq.edu.au/content/chap ter-6-growth-analysis-quantitative-approach

Läuchli A, Grattan S (2007). Plant growth and development under salinity stress. In: "Advances in molecular breeding toward drought and salt tolerant crops" (Jenks MA, Hasegawa, PM, Jain SM eds). Springer, The Netherlands, pp. 1-32. - doi: 10.1007/978-1-4020-5578-2_1 Lopez-Hoffman L, Anten NP, Martínez-Ramos M, Ackerly DD (2007). Salinity and light interactively affect neotropical mangrove seedlings at the leaf and whole plant levels. Oecologia 150 (4): 545-556. - doi: 10.1007/s00442-006-0563-4 Mahmood H (2015). Handbook of selected plant species of the Sundarbans and the embankment ecosystem. German Development Cooperation (giz), Dhaka, Bangladesh, pp. 113.

Mahmood H, Saberi O, Japar Sidik B, Misri K (2008). Net primary productivity of Bruguiera parviflora (Wight and Arn.) dominated mangrove forest at Kuala Selangor, Malaysia. Forest Ecology and Management 255: 179-182. - doi: 10.1016/j.foreco.2007.09.011 Mahmood H, Saberi O, Misri K, Japar Sidik B (2006). Seasonal variation in concentrations of $\mathrm{N}, \mathrm{P}$ and $\mathrm{K}$ in different components of Bruguiera parviflora (Wight and Arnold) at three growth stages in Malaysia. Indian Journal of Forestry 29 (2): 149-155.

Mahmood H, Saha S, Siddique MRH, Hasan MN (2014a). Salinity stress on growth, nutrients and carbon distribution in seedlings parts of Heritiera fomes. International Journal of Environmental Engineering 1 (4): 71-77. [online] URL: http://www.researchgate.net/publication/ 270449828

Mahmood H, Saha S, Serajis S, Siddique MRH, Abdullah SMR (2014b). Salinity influence on germination of four important mangrove species of the Sundarbans, Bangladesh. Agriculture and Forestry 60 (2): 125-135. [online] URL: http://www.cabdirect.org/cabdirect/abstract/2 0143303739

Marschner H (1995). Functions of mineral nutrients: macronutrients. In: "Mineral Nutrition of Higher Plants ( $2^{\text {nd }}$ edn)". Academic Press, New York, USA, pp. 299-312. - doi: 10.1016/B978-0-08057187-4.50014-X

Munns R (1992). A leaf elongation assay detects an unknown growth inhibitor in xylem sap from wheat and barley. Functional Plant Biology 19 (2): 127-135. [online] URL: http://www. publish.csiro.au/fp/PP9920127

Munns R, Tester M (2008). Mechanisms of salinity tolerance. Annual Review of Plant Biology 59: 651-681. - doi: 10.1146/annurev.arplant.59. 032607.092911

Nandy P, Das S, Ghose M, Spooner-Hart R (2007). Effects of salinity on photosynthesis, leaf anatomy, ion accumulation and photosynthetic nitrogen use efficiency in five Indian mangroves. Wetland Ecology and Management 15 (4): 347-357. - doi: 10.1007/s11273-007-9036-8 Nguyen HT, Stanton DE, Schmitz N, Farquhar GD, Ball MC (2015). Growth responses of the mangrove Avicennia marina to salinity: development and function of shoot hydraulic systems require saline conditions. Annals of Botany 115 (3): 397-407. - doi: 10.1093/aob/mcu257

Olsen SR, Sommers LE (1982). Phosphorus. In: "Methods of soil analysis. Part 2, Agronomy

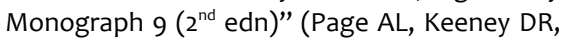
Baker DE, Miller RH, Ellis R, Rhoades JD eds). ASA and ASSA, Madison, USA. pp. 403-430. Paliyavuth C, Clough B, Patanaponpaiboon P
(2004). Salt uptake and shoot water relations in mangroves. Aquatic Botany 78 (4): 349-360. doi: 10.1016/j.aquabot.2004.01.002

Parida AK, Das AB (2005). Salt tolerance and salinity effects on plants: a review. Ecotoxicology and Environmental Safety 60 (3): 324-349. doi: 10.1016/j.ecoenv.2004.06.010

Patel NT, Gupta A, Pandey AN (2010). Strong positive growth responses to salinity by Ceriops tagal, a commonly occurring mangrove of the Gujarat coast of India. AoB PLANTS 2010: plq011. - doi: 10.1093/aobpla/plq011

Reef R, Lovelock CE (2015). Regulation of water balance in mangroves. Annals of Botany 115 (3): 385-395. - doi: 10.1093/aob/mcu174

Reich PB, Uhl C, Walters MB, Ellsworth DS (1991). Leaf lifespan as a determinant of leaf structure and function among 23 Amazonian tree species. Oecology 86 (1): 16-24. - doi: 10.1007/BFoo 317383

Schindelin J, Arganda-Carreras I, Frise E, Kaynig V, Longair M, Pietzsch T, Preibisch S, Rueden C, Saalfeld S, Schmid B, Tinevez JY (2012). Fiji: an open-source platform for biological-image analysis. Nature Methods 9 (7): 676-682. - doi: 10.1038/nmeth.2019

Siddiqi NA (2001). Mangrove forestry in Bangladesh. Institute of Forestry and Environmental Sciences, University of Chittagong, Chittagong, Bangladesh, pp. 201.

Suárez N, Medina E (2005). Salinity effect on plant growth and leaf demography of the mangrove, Avicennia germinans L. Trees 19 (6): 722728. - doi: 10.1007/s00468-005-0001-y

Taffouo VD, Braconnier S, Kenn M, Din N, Priso JR, Djiotie NL, Ako A (2008). Physiological and agronomical characteristics in Citrullus lanatus (Thumberg) mansfeld, Cucurbita moschata (Duchesne ex lam) and Lagenaria siceraria (Molina) stand under salt stress. African Crop Science and Society 8: 489-494.

Wei W, Bilsborrow PE, Hooley P, Fincham DA, Lombi E, Forster BP (2003). Salinity induced differences in growth, ion distribution and partitioning in barley between the cultivar Maythorpe and its derived mutant Golden Promise. Plant and Soil 250 (2): 183-191. - doi: 10.1023/ A:1022832107999

Ye Y, Tam NFY, Lu CY, Wong YS (2005). Effects of salinity on germination, seedling growth and physiology of three salt-secreting mangrove species. Aquatic Botany 83 (3): 193-205. - doi: 10.1016/j.aquabot.2005.06.006 